\title{
Radiation Monitoring of Agricultural Products as One of The Factors of Ecological Security of Population
}

\author{
Kazakov A.Yu. \\ Department of General Physics and Physics Teaching \\ Methods \\ Penza State University \\ Lermontov street 37, Russian Federation \\ e-mail o-fizika@yandex.ru
}

\author{
Tertychnaya S.V \\ Department of General Physics and Physics Teaching \\ Methods \\ Penza State University \\ Lermontov street 37, Russian Federation \\ svetter@mail.ru
}

\author{
Totsky O. Yu. \\ Totsky Farm LLC \\ Penza, Russia
}

\begin{abstract}
The Chernobyl disaster, which knows no analogies in the world in the scope of radioactive emission and duration, radionuclide composition and physical and chemical discharge forms, led to the large-scale pollution of agricultural lands and products, including animal production. After the Chernobyl disaster in Penza region the following figures in radioactive fallout were recorded $137 \mathrm{Cs}$ and $90 \mathrm{Sr}$. The aim of this research is to study and analyze the common factors of a radiation situation in agricultural production sphere in Penza and in its region.
\end{abstract}

Keywords- ${ }^{137} \mathrm{Cs},{ }^{90} \mathrm{Sr},{ }^{40} \mathrm{~K},{ }^{226} \mathrm{Ra}$, volumic activity, monotoring radiation security, radionuclide.

\section{INTRODUCTION}

After having conducted a set of actions aimed at radioactive pollution damage assessment and post-accident recovery and clean up in agriculture, some issues arose, which underlined the necessity to specify data on: the level of radioactive impurity with some radionuclides containing in feed-stuff, ration and animal products on the territory of the Russian Federation; the common factors and regularities in radionuclides migration along the chain - feeding - animal animal products; the normalization principles identifying radioactive substances in feed stuff; the criteria on controlling radioactive substances in agricultural products; the principals towards the development of reliable and eligible system for veterinary radiological monitoring based on some new techniques and methods dealing with radioactive control, analysis and prediction of a radioactive situation $[1,2]$.

As the main objectives of the research we point out: studying the content of radioactive pollution, containing in objects under veterinary inspection, caused by global and local radionuclides emissions and by a decline rate of concentration of such substances as ${ }^{40} \mathrm{~K},{ }^{226} \mathrm{Ra},{ }^{232} \mathrm{Th}$ and ${ }^{137} \mathrm{Cs}$ that contain in emissions; studying the peculiarities of polluting feed stuff and products for animals raising ${ }^{40} \mathrm{~K},{ }^{226} \mathrm{Ra},{ }^{232} \mathrm{Th}$ and ${ }^{137} \mathrm{Cs}$; identifying the risk assessment when radionuclides can be supplied in animals with feed stuff and ration, specifying the transmission ratios ${ }^{40} \mathrm{~K},{ }^{226} \mathrm{Ra},{ }^{232} \mathrm{Th}$ and ${ }^{137} \mathrm{Cs}$ from feed stuff into animal products within the period when these animals were used; studying and specifying some methodological and normalization aspects that feature a permissible level of radionuclides in feed stuff; rationale and development of State-based veterinary radiological control and monitoring system in the Russian Federation; development and improvements towards the veterinary rules and regulations, radiological control methods, veterinary-sanitary expertise and samples taking from the objects appearing in veterinary monitoring zone.

\section{METHODS AND MATERIALS}

In order to conduct some experimental studies addressed finding the basic radionuclides in the agricultural products samples under experiment we applied the gamma ray spectroscopy (Green Star (GS) "SKS-07P") that is intended to testing radionuclide specific activity in samples on three forms of radiation.

\section{RESULTS}

Close examination of the agricultural product samples feed stuff and pasturing soil intended for animal grazing (grown in Penza region) - taken for the analysis has shown that there is the necessity in carrying out more detailed examination of animal products.

Numerous tests, carried out on high-sensitivity spectroscopy equipment during 4 years by a group of Penza physicists, and targeted at radionuclide concentration in food products, animal products and feed stuff have shown in the objects under study the concentration of following radionuclides: $\mathrm{Cs}^{137}, \mathrm{Ra}^{226}, \mathrm{Th}^{232}, \mathrm{Am}^{241}, \mathrm{Rn}^{222}$. There were some cases with overconcentration (MPCs - maximum 
permissible concentrations) $[4,5,6]$. MPCs are introduced in table I.

TABLE I. PERMISSIBLE CONCENTRATIONS OF RADIONUCLIDES IN PRODUCTS AND WATER

\begin{tabular}{|l|c|}
\hline \multicolumn{1}{|c|}{ Product } & Specific activity, Bq/kg \\
\hline Drinking water & 18.5 \\
\hline $\begin{array}{l}\text { Milk, fermented milk products, sour cream, curd } \\
\text { cheese, cheese }\end{array}$ & 50 \\
\hline Butter, condensed and canned milk & 100 \\
\hline Powdered milk & 100 \\
\hline $\begin{array}{l}\text { Meat (pork, lamb), poultry, fish, eggs, meat and } \\
\text { fish products }\end{array}$ & 500 \\
\hline Beef meat and beef meat products & 400 \\
\hline Fats and oils, margarine & 40 \\
\hline Potato, vegetables, greens, fruit and berries & 80 \\
\hline Bread, cereals, flour, sugar & 40 \\
\hline Canned vegetables, fruit, berries, honey & 74 \\
\hline Baby food & 37 \\
\hline Dried garden fruit & 70 \\
\hline Forest food products & 370 \\
\hline
\end{tabular}

TABLE II. MILK PRODUCTS MONITORING (PENZA MANIFACTURERS)

\begin{tabular}{|c|c|c|c|c|c|c|}
\hline \multirow[t]{2}{*}{ Product } & \multirow{2}{*}{$\begin{array}{l}\text { Weigh } \\
\text { t kg }\end{array}$} & \multirow{2}{*}{$\begin{array}{c}\text { Measure } \\
\text { d by }\end{array}$} & \multicolumn{2}{|c|}{${ }^{226} \mathbf{R a}$} & \multicolumn{2}{|c|}{${ }^{137} \mathrm{Cs}$} \\
\hline & & & $B q / k g$ & $B q / l$ & $\begin{array}{c}B q / k \\
g\end{array}$ & $B q / l$ \\
\hline $\begin{array}{c}\text { Danish } \\
\text { cows milk } \\
2,5 \%\end{array}$ & 0.310 & GS & & & & \\
\hline $\begin{array}{c}\text { Danish } \\
\text { cows milk } \\
3,2 \% \\
\end{array}$ & 0.300 & GS & & & & \\
\hline Yogurt & 0.30 & GS & 6.11 & 1.656 & & \\
\hline Ryazhenka & 0.250 & GS & 27.33 & 6.123 & & \\
\hline Serum & 0.350 & GS & 27.89 & 9.42 & & \\
\hline $\begin{array}{l}\text { Bio-milk } \\
\text { products }\end{array}$ & 0.250 & $\overline{\mathrm{GS}}$ & 53.72 & 3.4 & & \\
\hline $\begin{array}{l}\text { Brynza } \\
\text { cheese }\end{array}$ & 0.200 & $\overline{G S}$ & 23.38 & 3.31 & & \\
\hline $\begin{array}{c}\text { Curd } \\
\text { cheese }\end{array}$ & 0.200 & GS & 46.32 & 3.2 & $\begin{array}{c}5.32 \\
1\end{array}$ & 0.62 \\
\hline $\begin{array}{c}\text { Curd } \\
\text { cheese } \\
\text { products } \\
\text { with greens }\end{array}$ & 0.150 & $\overline{G S}$ & 32.85 & 4.7 & & \\
\hline $\begin{array}{l}\text { Melty } \\
\text { cheese }\end{array}$ & 0.150 & $\overline{G S}$ & 8.25 & 1.21 & 9.08 & 0.89 \\
\hline $\begin{array}{l}\begin{array}{l}\text { Smoked } \\
\text { cheese }\end{array} \\
\end{array}$ & 0.200 & $\overline{G S}$ & 21.66 & 0.85 & 9.12 & 0.78 \\
\hline
\end{tabular}

\begin{tabular}{|c|c|c|c|c|c|c|}
\hline \multirow[t]{2}{*}{ Product } & \multirow{2}{*}{$\begin{array}{l}\text { Weigh } \\
\text { t kg }\end{array}$} & \multirow{2}{*}{$\begin{array}{c}\text { Measure } \\
\text { d by }\end{array}$} & \multicolumn{2}{|c|}{${ }^{232} \mathbf{T h}$} & \multicolumn{2}{|c|}{${ }^{40} \mathbf{K}$} \\
\hline & & & $\begin{array}{c}\mathbf{B q} / \mathbf{k} \\
\mathrm{g}\end{array}$ & $\mathrm{Bq} / \mathrm{l}$ & $\underset{\mathrm{g}}{\mathrm{Bq} / \mathbf{k}}$ & $\mathrm{Bq} / \mathrm{l}$ \\
\hline $\begin{array}{c}\text { Danish } \\
\text { cows milk } \\
2,5 \%\end{array}$ & 0.310 & GS & & & $\begin{array}{c}5 \\
157 . \\
2\end{array}$ & 46.16 \\
\hline $\begin{array}{c}\text { Danish } \\
\text { cows milk } \\
3,2 \%\end{array}$ & 0.300 & GS & & & $\begin{array}{c}176 . \\
8\end{array}$ & 33.25 \\
\hline Yogurt & 0.30 & GS & $\begin{array}{c}1.84 \\
1\end{array}$ & 0.487 & $\begin{array}{c}86.5 \\
5\end{array}$ & 23.31 \\
\hline Ryazhenka & 0.250 & $\overline{G S}$ & & & $\begin{array}{c}51.6 \\
7\end{array}$ & 11.57 \\
\hline $\begin{array}{l}\text { Malted } \\
\text { milk }\end{array}$ & 0.250 & $\overline{G S}$ & & & & \\
\hline Serum & 0.350 & GS & & & & \\
\hline $\begin{array}{l}\text { Bio-milk } \\
\text { products }\end{array}$ & 0.250 & GS & & & $\begin{array}{c}42.7 \\
3\end{array}$ & 3.89 \\
\hline $\begin{array}{l}\text { Brynza } \\
\text { cheese }\end{array}$ & 0.200 & GS & & & $\begin{array}{c}56.7 \\
5\end{array}$ & 14.67 \\
\hline $\begin{array}{l}\text { Curd } \\
\text { cheese }\end{array}$ & 0.200 & GS & & & $\begin{array}{c}67.7 \\
7 \\
\end{array}$ & 9.23 \\
\hline $\begin{array}{c}\text { Curd } \\
\text { cheese } \\
\text { products } \\
\text { with greens }\end{array}$ & 0.150 & GS & & & $\begin{array}{c}60.2 \\
5\end{array}$ & 11.33 \\
\hline $\begin{array}{l}\text { Melty } \\
\text { cheese }\end{array}$ & 0.150 & GS & & & $\begin{array}{c}152 . \\
4\end{array}$ & 25.7 \\
\hline $\begin{array}{l}\text { Smoked } \\
\text { cheese }\end{array}$ & 0.200 & $\overline{G S}$ & & & 57.7 & 33.2 \\
\hline
\end{tabular}

TABLE III. MEAT PRODUCTS MONITORING (PENZA MANIFACTURERS).

\begin{tabular}{|c|c|c|c|c|c|c|}
\hline \multirow[t]{2}{*}{ Product } & \multirow{2}{*}{$\begin{array}{c}\text { Weigh } \\
\text { t kg }\end{array}$} & \multirow{2}{*}{$\begin{array}{l}\text { Measu } \\
\text { red by }\end{array}$} & \multicolumn{2}{|c|}{${ }^{226} \mathbf{R a}$} & \multicolumn{2}{|c|}{${ }^{137} \mathrm{Cs}$} \\
\hline & & & $B q / k g$ & $B q / l$ & $B q / k g$ & $B q / l$ \\
\hline Chicken & 0.345 & GS & 10.93 & 5.26 & & \\
\hline Duck & 0.320 & GS & 175.2 & 33.75 & & \\
\hline Turkey & 0.356 & GS & 67.96 & 4.86 & & \\
\hline Beef & 0.367 & GS & 37.96 & 7.2 & & \\
\hline Pork & 0.326 & GS & 23.98 & 7.42 & & \\
\hline Lamb & 0.405 & GS & 19.2 & 1.34 & & \\
\hline
\end{tabular}

\begin{tabular}{|c|c|c|c|c|c|c|}
\hline Product & Weigh & Measu & \multicolumn{2}{|c|}{${ }^{232} \mathbf{T h}$} & \multicolumn{2}{|c|}{${ }^{{ }^{40} \mathbf{K}}$} \\
\cline { 4 - 7 } & $\mathbf{t ~ k g}$ & red by & $\boldsymbol{B q} / \boldsymbol{k g}$ & $\boldsymbol{B q} / \boldsymbol{l}$ & $\boldsymbol{B q} / \mathbf{k g}$ & $\boldsymbol{B q} / \boldsymbol{l}$ \\
\hline Chicken & 0.345 & GS & & & 124.5 & 54.1 \\
\hline Duck & 0.320 & GS & & & & \\
\hline Turkey & 0.356 & GS & 5.3 & 0.78 & 54.69 & 8.09 \\
\hline Beef & 0.367 & GS & 3.78 & 1.4 & 67.45 & 8.05 \\
\hline Pork & 0.326 & GS & 8.42 & 3.1 & & \\
\hline Lamb & 0.405 & GS & & & 176.1 & 28,71 \\
\hline
\end{tabular}




\section{CONCLUSION}

The results obtained within studying the issues set up in this research allowed us to make the following conclusions:

1) the material that was reviewed showed that in changes

TABLE IV. MONITORING ON FOOD PRODUCTS FOR FARM ANIMALS.

\begin{tabular}{|c|c|c|c|c|c|c|}
\hline \multirow[b]{2}{*}{ Product } & \multirow{2}{*}{$\begin{array}{l}\text { Weigh } \\
\text { t kg }\end{array}$} & \multirow{2}{*}{$\begin{array}{l}\text { Measu } \\
\text { red by }\end{array}$} & \multicolumn{2}{|c|}{${ }^{226} \mathbf{R a}$} & \multicolumn{2}{|c|}{${ }^{40} \mathrm{~K}$} \\
\hline & & & $B q / k g$ & $B q / l$ & $B q / k g$ & $B q / l$ \\
\hline $\begin{array}{l}\text { Mixed feed } \\
\text { for chicken }\end{array}$ & $\begin{array}{l}0.098 \\
\end{array}$ & GS & 11.4 & 1.117 & 747.6 & 73.26 \\
\hline $\begin{array}{l}\text { Mixed feed } \\
\text { for Danish } \\
\text { cows }\end{array}$ & 0.142 & GS & 18.36 & 2.6 & 404.3 & 57.41 \\
\hline $\begin{array}{l}\text { Mixed feed } \\
\text { for local } \\
\text { domestic } \\
\text { cows }\end{array}$ & 0.136 & GS & 40.9 & 5.56 & 138.7 & 18.86 \\
\hline $\begin{array}{l}\text { Nutritional } \\
\text { supplement } \\
\mathrm{s} \text { for cows }\end{array}$ & 0.100 & GS & & & 569.5 & 56.95 \\
\hline $\begin{array}{l}\text { Nutritional } \\
\text { supplement } \\
\mathrm{s} \text { for } \\
\text { pregnant } \\
\text { cows }\end{array}$ & 0.142 & GS & 81.25 & 10.48 & 215.4 & 27.78 \\
\hline Silage & 0.142 & GS & & & 249.8 & 35.47 \\
\hline Hay & 0.105 & GS & 26.17 & 2.75 & 352.8 & 35.28 \\
\hline Straw & 0.120 & GS & 33.15 & 5.47 & 278.3 & 28.13 \\
\hline
\end{tabular}

Based on the measurements carried out in most cases we can conclude that such dangerous substances ${ }^{226} \mathrm{Ra},{ }^{232} \mathrm{Th}$, ${ }^{137} \mathrm{Cs}$ in the objects under examination have been in MPCs. Most products are rich with ${ }^{40} \mathrm{~K}$ that is necessary for human organism and health.

The important factor for preventing accumulation of radionuclides in people's organism, who live or work near or in the territories polluted with emergency emissions, is using particular food products and their components. Specifically it relates to long-living radionuclides (for example, ${ }^{90} \mathrm{Sr}$ ), which are able to migrate along the food chains, being accumulated in organism and tissues, expose bone marrow and bone tissue to chronicle radiation, increasing by it the risk to malignancies formation.

It turns out that food fortification with fish, calcium, bone flour, fluorine, and seaweeds contribute to reducing a cancer diseases risk.

A big interest in this context is introduced by indigestible carbohydrates, which are used in nutrition purposes particularly for food products prescribed in treatment and prophylactic aims.

Considerable importance in prophylactic radioactive impact has beta-carotene and food products with high concentration of this pro-vitamin.

To reduce the radiation dose on population can be achieved by the target optimization of agricultural production structure, using the factor that in farm products the radionuclide concentration is 2-4 times less than in products of crop production. The basic part of radionuclides supplied into organisms with food ration occurs through intaking of vegetables products, such as cabbage and potato. in natural radiation level of environment a great role plays atomic power stations, nuclear explosions and radioactive waste. The adverse security situation in Penza region is caused by high concentration of artificial radionuclides $\left({ }^{137} \mathrm{Cs},{ }^{90} \mathrm{Sr}\right.$, $\left.{ }^{40} \mathrm{~K},{ }^{226} \mathrm{Ra} \mathrm{и} \mathrm{и}{ }^{241} \mathrm{Am}\right)$. The Chernobyl disaster conditioned the environmental pollution mainly with ${ }^{137} \mathrm{Cs}$ [3].

2) the products produced in Penza region that were under examination showed a high concentration of ${ }^{40} \mathrm{~K}$. it is observed in such products as: cabbage, domestic carrot, cheese, and bread; ${ }^{137} \mathrm{Cs}$ is found in cabbage, smoked sausage and in bread; ${ }^{226} \mathrm{Ra}$ is found in bread. Less concentration of ${ }^{40} \mathrm{~K}$ is found in buck wheat, cucumbers, and smoked sausage; ${ }^{137} \mathrm{Cs}$ is observed in macaroons and buck wheat; ${ }^{226} \mathrm{Ra}$ is in carrot, tomato, potato, and cucumbers.

In products from Danish cows the concentration of substances under examination is significantly low because the feed stuff for them is grown separately, when the pastures are planted with grass imported to Russia together with the cowcattle.

For 20 years that passed since the Chernobyl disaster the value of the average activity of ${ }^{137} \mathrm{Cs}$ in Penza lands (soils) has decreased from $1.5 \mathrm{Cu} / \mathrm{km}^{2}$ till $0.121 \mathrm{Cu} / \mathrm{km}^{2}$ that means 10 times less. It is not surprisingly and mostly connected with the fact that the half-life period of ${ }^{137} \mathrm{Cs}$ equals to 30 years, but the decrease in activity is going exponentially.

Detection in soils ${ }^{241} \mathrm{Am}$ is mainly connected with nuclear tests that were taken place in Semipalatinsk, in Novaya Zemlya and etc. but not directly related to the Chernobyl case. By the reason that neutron capture at nuclear tests is happening during a very short time and it results in transuranium elements formation with a very big atomic weight (americium, berkelium, curium and etc.). Another case is with radionuclides formation, when they are in a reactor, the neutrons are captured occasionally and the product obtained can dissociate before additional neutrons are captured. The half-life period of ${ }^{241} \mathrm{Am}$ is about 500 years. Therefore, in the nearest centuries ${ }^{241} \mathrm{Am}$ will be in soils. Moreover, ${ }^{241} \mathrm{Am}$ is a radioactive product of plutonium - $241 \quad\left({ }^{241} \mathrm{Pu}\right)$, whose radioactive decay is 14.4 years, but ${ }^{241} \mathrm{Pu}-$ a radioactive product of curium $-245\left({ }^{245} \mathrm{Cm}\right)$, whose half-time period is 8 500 years. The ${ }^{241} \mathrm{Am}$ dissociates up to neptunium $237(237 \mathrm{~Np})$, and its radioactive decay period is $2,14 \cdot 10^{6}$ years; its finding is also possible in the nearest time after the additional calibration of a spectrometer.

The artificial radioactive elements in soils are significant supplementation to the natural radiation background to which living organisms have some time difficulties to adapt. When one radionuclides are dissociated, the others are formed and we have the chain reaction that is going quicker than evolution. A human organism does not manage to adapt and this entails the negative impacts on people's health because apart from radiation background rise there is happening the 
internal exposure. This can lead to malignant tumours formation.

\section{References}

[1] SNiP 1.02.07-87 (Russian standarts), Engineering Survey for Constructions. Moscow. USSR Construction Department, 1988.

[2] SNiP 2.6.1.2523-09 (Russian standarts), Radiation Security Norms, Moscow, Energoatomiszdat, 2009.

[3] Sources and Actions of Ionizing Radiation: Reports in UNO meetings for 2006: General Assembly in New York, Vol. 1-3, 2006.

[4] A.I. Abramov, Yu.A. Kazanskiy, E.S. Matusevich, Basic Laws of Experimental Methods in Nuclear Physics, Moscow. Atomizdat, 1970.

[5] Spectrometric complex SKS-07P. Operating Instructions ABLK.412131.406 PA. 28 p.

[6] M.V. Kalmykov, Radioation Control and Monitoring of Agricultural Products in Conditions of Global and Local Radioactive Emissions, Moscow, 2001. 